\title{
The preferences in selecting dietary supplements used in slimming
}

\begin{abstract}
Introduction. The interest in weight loss supplements can be noticed in Poland at the moment. It is related to people's trying to look good as fast as possible. The pharmaceutical market puts an emphasis only on the benefits and majority of the people purchasing the supplements do not regard doctor's advice as necessary. Therefore, in order to learn about consumers' awareness about the use of dietary supplements is gaining importance.

Aim. The objective of the study was to gain knowledge about choice preferences of dietary supplements used in weight loss, like also to learn about consumer's awareness about the use of dietary supplements.

Material and methods. An anonymous survey was conducted in Mielec in 2015 among 112 women. The questionnaire included questions concerning their knowledge of dietary supplements, the type and amount of consumption, the reasons for using supplements, benefits and health risks of their use.

Results. $90.2 \%$ of women admitted that they are using or they used dietary supplements in order to reduce weight. Respondents most often derive the information about these preparations from the pharmacist (62.5\%), television (46.4\%), a doctor (36.6\%), radio (30.4\%), the Internet (29.5\%). $72.4 \%$ of female respondents pay attention to the composition of dietary supplement, with the emphasis on the amount of the ingredients $(64.3 \%)$, its dosage $(55.4 \%)$, the origin of the ingredients (natural or synthetic) $(37.5 \%)$. Female respondents prefer dietary supplements either in the form of tablets $(83.9 \%)$ and capsules $(54.7 \%)$, as well as in liquid (52.7\%).

Conclusions. Respondents showed an increased interest in supplements used for weight loss and they usually use it in forms of tablets and capsules. As the role of the Internet increases, it is necessary to educate consumers about ability to search reliable sources of information about dietary supplements used for weight loss.
\end{abstract}

Keywords: dietary supplements, weight loss, women, preferences.

DOI: $10.1515 /$ pjph-2016-0035

\section{INTRODUCTION}

According to data provided by the World Health Organization (WHO) a number of overweight and obese individuals has increased worldwide. Every fifth person living in Europe is affected by that condition. Various research studies show that in approximately $21 \%$ of women experience episodes of overeating, while some $40 \%$ of women have an excessive body weight [1]. In Poland, every third woman and every second man is overweight, and every third woman and every fourth man suffers from obesity. These illnesses are related to the biological, psychological and environmental determinants and result in numerous negative health consequences.

Excessive weight and obesity in particular, can become a risk factor causing numerous chronic non-infectious diseases to happen. For instance, they may contribute to the development of cardiovascular, respiratory system diseases, type II diabetes, atherosclerosis or neoplastic diseases [2]. In order to combat these diseases in a satisfactory way, it is essential to introduce a special diet, and supplementation, physical ac- tivity, as well as avoid noise and ensure stress management. The dietary supplements which support slimming usually contain substances which are expected to boost metabolism, increase fat burning, inhibit appetite as well as, impede an absorption of the energetic ingredients eaten with food.

In the $21^{\text {st }}$ century one can acquire a great number of information about the new dietary supplements thanks to which you can lose even a few dozen kilograms in a short period of time. A great increase in the demand for such type of preparations has been noticed. Therefore, the market of weight loss supplements increases day by day. Among others, it is related to an opinion that food that people eat is deprived of nutrients, particularly when talking about food that undergoes technological processing. There is also a group of individuals that simply want to improve their appearance. Therefore, so important is an observation and the studies related to a quantity and frequency of using the dietary supplements by the relevant populations, because an improper usage of an excessive amount of the preparations may lead to the negative health consequences [3]. 
When selecting a certain product, consumers are very likely to focus on the information written on the package or an attached leaflet. The dietary supplements used for slimming create associations with taking care for a healthy lifestyle, and first of all, with a beautiful, slim body. Furthermore, customers are often encouraged that they can "lose kilograms without any food and training sacrifices" by the advertisements. It is often used by the entrepreneurs who promote and distribute this kind of preparations in the market.

In Poland, there is huge demand for dietary supplements by a group of individuals who lead an active lifestyle, including individuals who practice different sport and recreation disciplines. In the pharmaceutical market there is a dynamic increase in supply of the various forms of the supplements intended for the physically active individuals, unfortunately a small amount of them has a scientifically confirmed efficacy [4].

Marketing of pharmaceutical products puts an emphasis on the advantages only, paying special attention to health and food advantages. This results from a convenient manner of supplementing in deficient nutrients during the different diets, for example restriction, slimming, for those who practice sports, in different physiological conditions or disorders. It is alarming that having heard such information, most people purchasing weight loss products do not feel the urge to consult their use with a physician [5]. Therefore, it becomes so important to get to know a level of consumers' awareness with regard to using the dietary supplements, in that - in relation to the supplements used within a slimming process.

\section{AIM}

The objective of this study was to learn about the preferences in selecting the dietary supplements used for weight loss. The respondents have been chosen at random. During the study, attempts were made to determine a level of consumers' awareness linked to the used dietary supplements, their advantages and disadvantages, as well as the results of using the dietary supplements and also perceived safety of administering them.

\section{MATERIAL AND METHODS}

In order to achieve the previously assumed objective of the study, a questionnaire survey was distributed in various drugstores located in Mielec. A questionnaire created by the authors has contained - besides the questions of the metric nature - the questions that were focused on the respondents' knowledge about the weight loss supplements and a type and an intake volume during the previous 3 months, as well as the questions concerning the reasons for administering supplements, and also health advantages and threats resulting from the supplementation. In the analysis of the research results there has been applied a chi-square test for independence and a correspondence analysis. All calculations were made using the suitable procedures of the Statistica 12 package.

The research was conducted in 2015. 112 women aged between 18-60 years old, residents of Mielec and the neighboring areas. A specification of the studied population has been presented in Table 1.

The most numerous group of the interviewees were women aged between 31-40 years old, residents of the rural areas, with a vocational or secondary education, who regard their financial status as average.
TABLE 1. The specification of studied population.

\begin{tabular}{lccc}
\hline \hline \multirow{2}{*}{ Specification } & n & \% \\
\hline & 18-30 years old & 22 & 19.6 \\
\cline { 2 - 4 } & 31-40 years old & 48 & 42.9 \\
\cline { 2 - 4 } & 41-50 years old & 26 & 23.2 \\
\cline { 2 - 4 } Place of residence & 51-60 years old & 16 & 14.3 \\
\cline { 2 - 4 } & Town & 20 & 17.9 \\
\hline \multirow{2}{*}{ Level of education } & Village & 92 & 82.1 \\
\cline { 2 - 4 } & Vocational or secondary & 70 & 63.5 \\
\hline \multirow{2}{*}{ Financial situation } & Higher & 42 & 37.5 \\
\cline { 2 - 4 } & Very good or good & 25 & 22.3 \\
\cline { 2 - 4 } Marital status & Average & 87 & 77.7 \\
& Married & 56 & 50.0 \\
\cline { 2 - 4 } & Single, divorced or & 56 & 50.0 \\
\hline
\end{tabular}

Source: Own elaboration on the basis of the conducted studies.

\section{RESULTS}

The respondents were asked about their own perception of their bodies, reasons for using the dietary supplements for weight loss, the places that they bought these products in, and the sums of money they spent on purchasing. The questionnaire also included questions about the factors that the respondents focus on while choosing the dietary supplements. A vast majority of the respondents has determined their body weight as above-standard $-31.3 \%$ considers that they are overweighed and $34.8 \%$ - that obese. Among the interviewees, $90.2 \%$ have confirmed that they use or have administered the dietary supplements in order to reduce their body weight. Usually, the respondents receive information about these preparations from a pharmacist $(62.5 \%)$, from TV $(46.4 \%)$, from a physician $(36.6 \%)$, from radio $(30.4 \%)$, from the Internet $(29.5 \%)$, from a dietician $(26.8 \%)$, from their acquaintances $(24.1 \%)$, from the newspapers $(19.6 \%)$ and from the leaflets $(20.5 \%)$. An apothecary shop is the most common place of purchasing the dietary supplements (67.0\%), and subsequently the Internet (55.4\%) and the herbal shop (42.9\%). The price is the most important factor affecting the buy decisions in case of dietary supplements (55.4\%); as well as the availability of the product $(43.8 \%)$. Most respondents $(60.7 \%)$ spend up to 50 PLN per month on these preparations. Almost $1 / 4$ of the respondents $(24.3 \%)$ spends up to 100 PLN for this every month. A majority of the respondents $(72.4 \%)$ pays attention to a composition of the dietary supplement, whereas they pay the greatest attention to a number of the preparation ingredients $(64.3 \%)$, its dosing $(55.4 \%)$, an origin of preparation ingredients (natural ingredients) (37.5\%), and finally to a type of the formulation $(36.6 \%)$. The respondents prefer the dietary supplements in a form of tablets $(83.9 \%)$ and capsules $(54.7 \%)$, as well as the preparations in a form of liquids $(52.7 \%)$. Even $61.6 \%$ of the respondents thinks that administering the dietary supplements is not necessary to maintain a nice shape of the body. Nearly $1 / 4$ of the respondents $(23.8 \%)$ is deeply convinced about this. Regarding the safety of using dietary supplements, the opinions are divided: $42.0 \%$ of the respondents concern it as safe, $35.7 \%$ of the respondents think they are not safe, and $22.3 \%$ have no specified view about this issue. 
TABLE 2. The values of statistics of the test for independence $\left(\mathrm{Chi}^{2}\right)$.

\begin{tabular}{|c|c|c|c|}
\hline Specification of features & Age & Education & $\begin{array}{c}\text { Marital } \\
\text { status }\end{array}$ \\
\hline Perception of one's own body weight & 6.842 & 1.042 & 1.355 \\
\hline Administering supplements & 5.344 & 0.717 & 0.737 \\
\hline Reason of administering & 5.038 & 1.330 & 0.393 \\
\hline $\begin{array}{l}\text { The Internet as a source } \\
\text { of information about supplements }\end{array}$ & 2.052 & 0.484 & 0.387 \\
\hline $\begin{array}{l}\text { A physician as a source } \\
\text { of information about supplements }\end{array}$ & 0.796 & 0.326 & 0.962 \\
\hline $\begin{array}{l}\text { A dietician as a source } \\
\text { of information about supplements }\end{array}$ & 3.581 & 0.912 & 0.670 \\
\hline $\begin{array}{l}\text { Television as a source } \\
\text { of information about supplements }\end{array}$ & 1.331 & 0.345 & 1.292 \\
\hline $\begin{array}{l}\text { Radio as a source } \\
\text { of information about supplements }\end{array}$ & 2.341 & 1.363 & 0.676 \\
\hline $\begin{array}{l}\text { A pharmacist as a source } \\
\text { of information about supplements }\end{array}$ & 3217 & 1.717 & 1.371 \\
\hline $\begin{array}{l}\text { A family/friends as a source } \\
\text { of information about supplements }\end{array}$ & 2.726 & 3.127 & 0.439 \\
\hline $\begin{array}{l}\text { Newspapers as a source } \\
\text { of information about supplements }\end{array}$ & 5.672 & 0.739 & 0.634 \\
\hline $\begin{array}{l}\text { Leaflets as a source } \\
\text { of information about supplements }\end{array}$ & 7.117 & 0.856 & 0.815 \\
\hline $\begin{array}{l}\text { The Internet as a place } \\
\text { of purchasing supplements }\end{array}$ & 5.257 & 1.628 & 0.578 \\
\hline $\begin{array}{l}\text { An apothecary as a place } \\
\text { of purchasing supplements }\end{array}$ & 1.953 & 2.586 & 1.009 \\
\hline $\begin{array}{l}\text { A herbal shop as a place } \\
\text { of purchasing supplements }\end{array}$ & 1.541 & $3.859 \%$ & 0.146 \\
\hline $\begin{array}{l}\text { A supermarket as a place } \\
\text { of purchasing supplements }\end{array}$ & 1.184 & 0.128 & $3.752 \%$ \\
\hline $\begin{array}{l}\text { A price as a factor } \\
\text { of purchasing supplements }\end{array}$ & $10.982 *$ & 1.627 & $8.249 *$ \\
\hline Availability & 3.465 & 2.034 & $4.590 *$ \\
\hline Convenience & 3.682 & 2.052 & 0.584 \\
\hline A vicinity to the place of residence & 6.850 & 0.896 & $3.976 *$ \\
\hline Quality & 1.247 & 0.912 & 1.520 \\
\hline $\begin{array}{l}\text { The amount of money intended } \\
\text { for purchasing supplements }\end{array}$ & 3.345 & 0.314 & 2.403 \\
\hline Paying attention to product composition & 4.664 & 1.859 & 1.465 \\
\hline $\begin{array}{l}\text { Ingredient type as the main factor } \\
\text { when purchasing supplements }\end{array}$ & 0.426 & 1.131 & 0.346 \\
\hline $\begin{array}{l}\text { A dosage of ingredients as the key factor } \\
\text { when purchasing supplements }\end{array}$ & 0.945 & 1.166 & 0.154 \\
\hline $\begin{array}{l}\text { A number of ingredients as the key factor } \\
\text { when purchasing supplements }\end{array}$ & 1.990 & 0.664 & 0.164 \\
\hline $\begin{array}{l}\text { Presence of natural ingredients as a factor } \\
\text { deciding about purchasing supplements }\end{array}$ & 0.378 & 2.286 & 0.810 \\
\hline $\begin{array}{l}\text { Liquids as a preferred } \\
\text { form of dietary supplements }\end{array}$ & 1.108 & 0.117 & 0.895 \\
\hline $\begin{array}{l}\text { Tablets as a preferred } \\
\text { form of dietary supplements }\end{array}$ & 0.246 & 0.590 & 0.265 \\
\hline $\begin{array}{l}\text { Capsules as a preferred } \\
\text { form of dietary supplements }\end{array}$ & 5.497 & 0.538 & 2.312 \\
\hline $\begin{array}{l}\text { Lozenges as a preferred } \\
\text { form of dietary supplements }\end{array}$ & 4.320 & 0.539 & 0.676 \\
\hline $\begin{array}{l}\text { Powders as a preferred } \\
\text { form of dietary supplements }\end{array}$ & 2.309 & 0.457 & $3.983 *$ \\
\hline $\begin{array}{l}\text { Drops as a preferred } \\
\text { form of dietary supplements }\end{array}$ & 4.265 & 0.159 & 2.391 \\
\hline $\begin{array}{l}\text { Ampoules filled with liquid as a preferred } \\
\text { form of dietary supplements }\end{array}$ & 3.174 & 2.263 & $3.772 *$ \\
\hline $\begin{array}{l}\text { Is administering dietary } \\
\text { supplements necessary? }\end{array}$ & 7.851 & 0.679 & 2.663 \\
\hline $\begin{array}{l}\text { Is administering dietary } \\
\text { supplements safe? }\end{array}$ & 2.084 & $11.200 *$ & 1.802 \\
\hline
\end{tabular}

Source: Own elaboration on the basis of the conducted studies.

*The symbol* means statistically significant value of $\mathrm{Chi}^{2}$ at the significance level of 0.05
The answers to the survey questions have been summarised with the selected social and economic features (age, education, marital status; a place of residence has not been taken into account due to a disproportion in the group size). For analyzing the research results, a Pearson's chi-squared test for independence was used. The hypothesis about an independence of the features was rejected, if a calculated value of the test statistics has exceeded a critical value with an assumed level of statistical significance $(\alpha=0.05)$. The values of the chi-squared test for independence are shown in Table 2.

One's age is one of the factors that affects respondents' attitudes to the prices of dietary supplements. The education differentiates opinions of the respondents in the case of a place of buying the supplements which is a herbal shop and the opinions related to safety of administering the supplements. Also, respondents' marital status affects their attitudes regarding supermarkets as place for purchasing the supplements and in connection to a few reasons of their buy, which are as follows: a price, an availability of a preparation in the buy place and a small distance of a place of selling from a place of residence. Furthermore, a marital status differentiate the answers of the respondents with regard to the preferred form of the supplements, i.e. supplements in the powder form and in the form of the ampoules with liquid.

At the next stage of the analysis, a multiple correspondence analysis has been applied (for the statistically significant values of chi-squared). The procedure was aimed to identify and evaluate the co-occurrence of the variable categories (and not the variables themselves). This method enables to create a graphical illustration of the relations between the categories of the variables. Therefore, it is possible to classify these observations (categories of the variables) in the characteristic aggregations.

In Figure 1, the co-occurrence of the social and economic features and a preferred place of buy of the dietary supplements used for weight loss is presented.

As it results from a configuration of the various categories presented in Figure 1, a herbal shop is the place where single women with secondary education would be purchasing dietary supplements. Decidedly a supermarket is not a place where they buy the dietary supplements. In turn, it is just a supermarket, and not a herbal shop, where married women with higher education buy the dietary supplements.

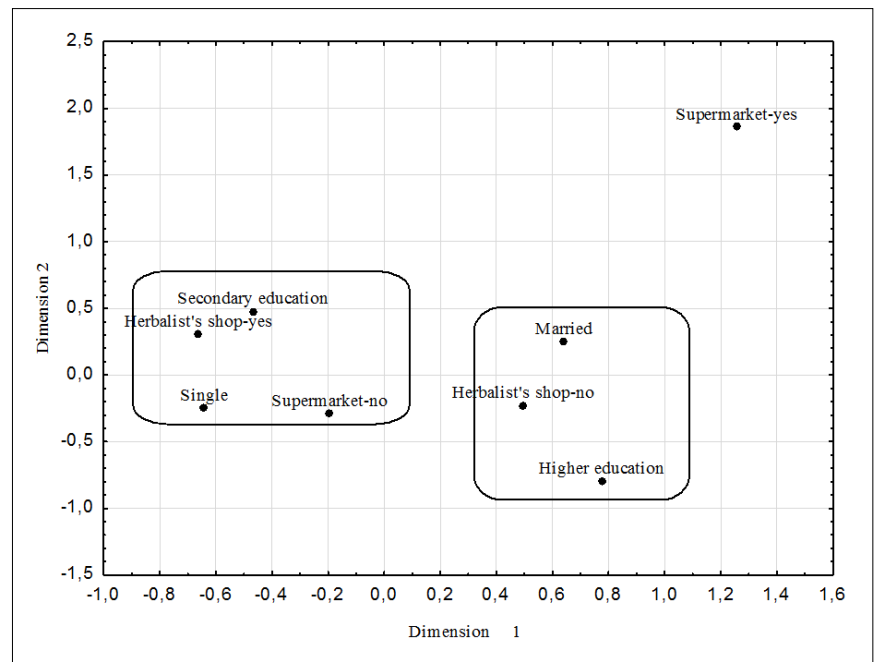

FIGURE 1. The preferred place of buy vs. social and economic factors the results of a correspondence analysis.

Source: Own elaboration on the basis of the conducted studies. 
The next figure (Figure 2) illustrates a co-occurrence of the social and economic features and the factors that determine the decision about buying the dietary supplements used in slimming.

When considering a co-occurrence of the variable categories it can be stated that for the single women aged 18-30 and 41-50, the price plays a key role while buying weight loss supplements. However, for these groups of the respondents neither a vicinity of the sales points of these supplements nor their availability in these sales points. It is the two features and not

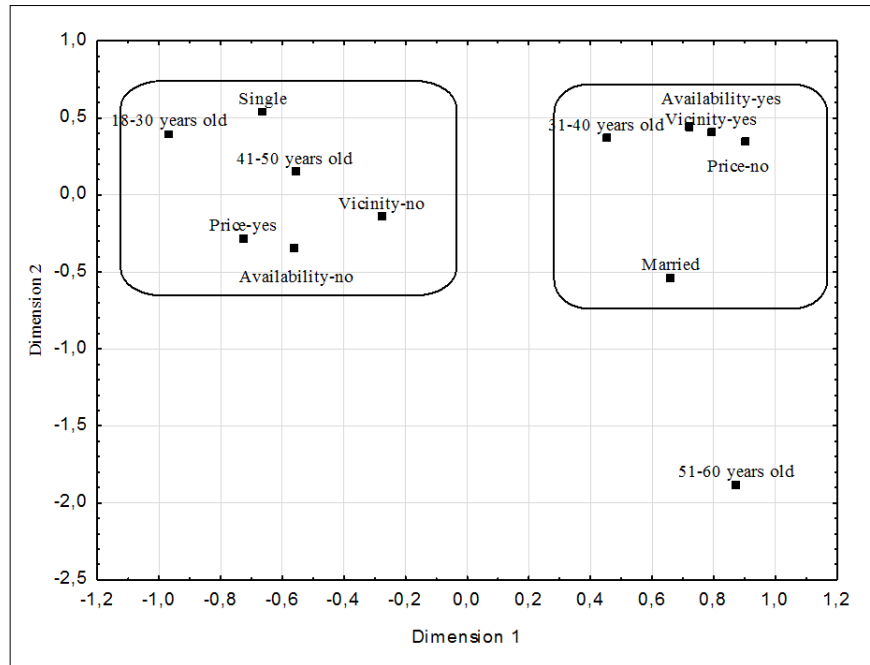

FIGURE 2. The factors which determine a buy vs. social and economic factors - the results of a correspondence analysis.

Source: The authors' own elaboration on the basis of the conducted studies.

a price that determine the decision about buying the supplements for married women aged 31-40.

Figure 3 presents a co-occurrence of the social and economic features and a preferred form of the dietary supplements used in slimming.

A neighborhood of the variable categories indicates that the married women prefer the powders as a form of the dietary supplement, but they do not prefer them in the form of the ampoules. The single women decidedly do not prefer the dietary supplements in form of powders.

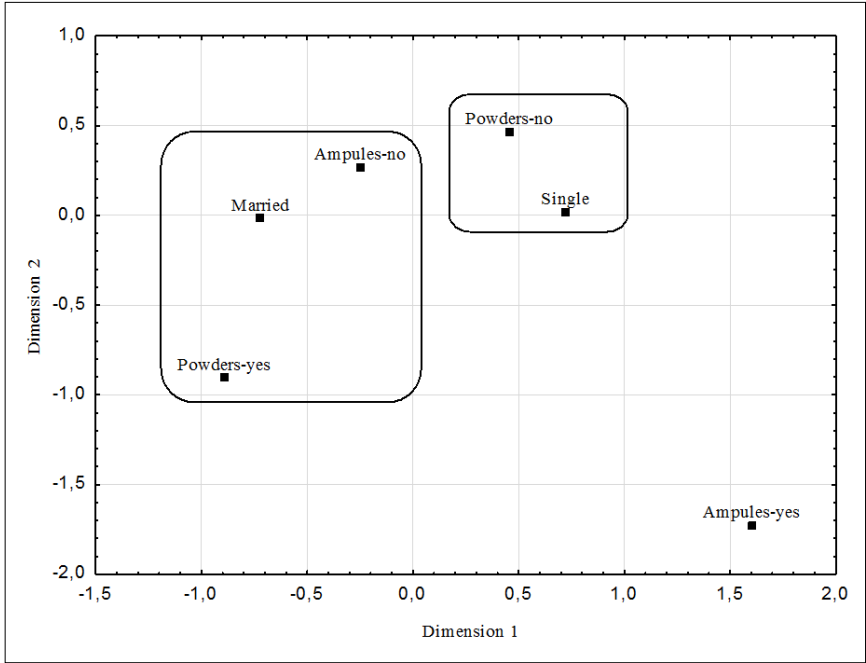

FIGURE 3. The preferred form of supplements vs. social and economic factors - the results of a correspondence analysis.

Source: Own elaboration on the basis of the conducted studies.
The last figure (Figure 4) illustrates a co-occurrence of the social and economic features and an opinion about safety of the dietary supplements used for losing weight.

When analysing a position of the variable categories, it can be noticed that from a point of view of women with secondary education the dietary supplements used for weight loss are completely safe. Nevertheless, the women with higher education have no explicitly expressed opinions about this issue.

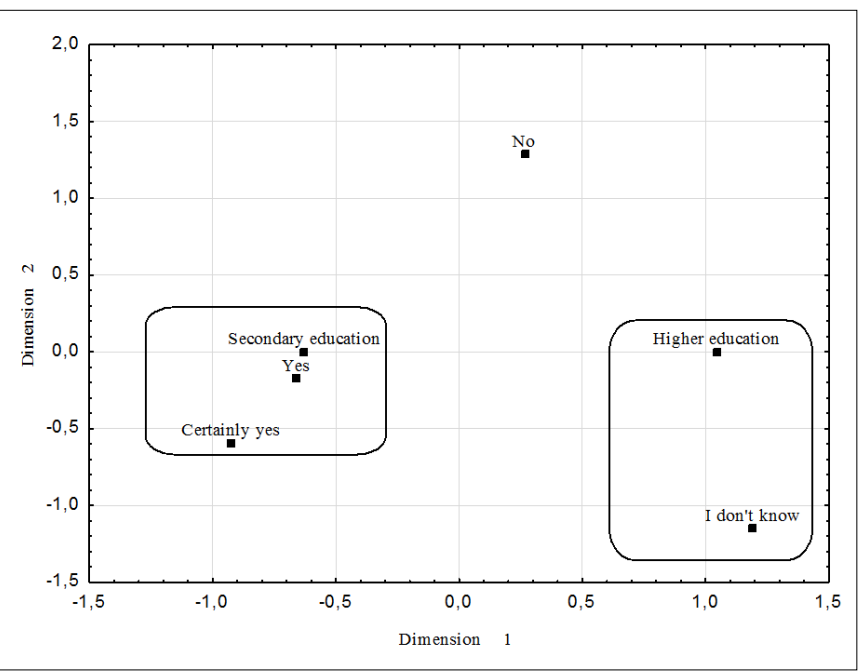

FIGURE 4. The opinion about safety of the supplements vs. social and economic factors - the results of a correspondence analysis.

Source: Own elaboration on the basis of the conducted studies.

\section{DISCUSSION}

A desire to have a slim body is gaining an increasing popularity, in particular among women (men are less affected by it). Among the students of the Warsaw University of Life Sciences (WULS) who use the slimming preparations, a vast majority has constituted women $42.4 \%$, while men constitute $20 \%$. The main reason for administering the dietary supplements included esthetic concerns (63.8\%), a low self-esteem (48.3\%) and the fashion for a slim silhouette $(29.3 \%)$. An increasing number of people reach for this kind of products in order to achieve or maintain a sleek silhouette [6]. Kryska reported there were more individuals who willingly reach for the dietary supplements that support the weight loss process $-80.3 \%$ of the overweight and obese students surveyed by her have not indicated that the dietary supplements as the second (after a diet) way of reducing their body weight [7]. In the own research a percentage of women who use the supplements in order to reduce body weight is slightly higher $-90.2 \%$ and $85.4 \%$ of the respondents have the opinion that the dietary supplements should be used not only to reduce their body weight, but also in order to maintain it for a longer time.

In the research studies conducted by Krejpcio et al. $60 \%$ of the interviewees have used the dietary supplements. They have done it as a result of the trainers' recommendations (72\%), their friends' recommendations $(60 \%)$, but only $4 \%$ have consulted using the dietary supplements with either a physician or a dietician. As the source of information, the respondents indicated: the Internet (76\%), trainers' opinions $(75 \%)$, acquaintances $(60 \%)$ and newspapers $(6 \%)$, whereas $90 \%$ of the interviewees regard the supplements as safe, and only $12 \%$ of respondents pay attention to information contained on the supplement packaging [7]. The authors' own studies produced 
some little bit different results: the Internet is a source of information for $29.5 \%$ of the respondents, $42 \%$ of the surveyed individuals, that the dietary supplements are safe, and $72.4 \%$ pays attention to information contained on the packaging. An existing fact can be explained that a trust in the preparations which support slimming is lower than in the case of the vitamin and mineral preparations (the most frequently administered by the Krejpcio's et al. respondents).

Most respondents who have taken part in the Spiołek's et al. study find information about the dietary supplements using the Internet (55\%). Other respondents mentioned newspapers (38\%), as well as the advice from their acquaintances (32.5\%) [8]. The Internet, as the main source of information about the dietary supplements, has been also evidenced in studies by Wybieralska - it was the main source of information about these formulations for $52 \%$ of the respondents [9]. In the studies conducted among 300 students from the West Pomeranian University of Technology in Szczecin, the preferences for a selection of slimming preparations were: price $(47.8 \%)$, physician's and pharmacist's advice (18.2\%), friend's advice $(21 \%)$, product quality $(18.5 \%)$. The results of these studies confirm that young people very often use information from the Internet $(39.5 \%)$, television $(27.7 \%)$, leaflets $(11.8 \%)$, from a pharmacist $(10.1 \%)$ and newspapers (5\%) [10]. The authors' own studies have shown that some $29.5 \%$ of the respondents mentioned the Internet as source of information, $19.6 \%$ - the newspapers, for television $-46.4 \%$ indications, whereas the pharmacist's advices have been a source of information for $62.5 \%$ of the respondents. Such a high percentage, in comparison with findings of other authors, can result from an impact of a place when the studies have been conducted (stationary sales points in Mielec are poorly supplied). A degree of importance of the price as a factor for buying the products that support slimming in the authors' own studies is similar $-55 \%$ indications for this determinant. Unlike other studies, the research conducted by the authors of this study showed that the surveyed individuals, as an important factor in purchasing the dietary supplements used in slimming, have stated their availability (43.8\%).

For $64.0 \%$ students surveyed by Kościółek et al. a form of the vitamin and mineral preparations has been of importance when choosing a concerned dietary supplement. The most often selected forms of the supplements have been tablets (51.5\% responses) [11]. In the own studies for this category of the supplements $83.9 \%$ indications have been obtained.

In the Szpringer's et al. researches a vast majority has declared that a main place of buying over-the-counter drugs and dietary supplements is an apothecary shop (55.6\%) [12]. As informed by Ciszek and Duma, $87.3 \%$ of the women surveyed by them buy the dietary supplements in the apothecary shop [13]. Even a higher percentage of the indications has been obtained by Spiołek et al. - even $98 \%$ of the respondents buy the dietary supplements in the apothecary shop [8]. The similar percentage $-95.7 \%$ of the responses - has been received by Kościółek et al. [11]. In this context the results of the own studies are similar to the results obtained by Szpringer, and constitute $67 \%$ of the indications for the apothecary shop as a place of purchasing the dietary supplements and correspond with the PMR Research Group communications, where $64 \%$ respondents have declared that buy the supplements only in the apothecary shop [14].

\section{CONCLUSIONS}

1. The respondents have shown great interest in the supplements used during a therapy of reduction an excessive amount of fat tissue and most often they reach for the tablets and capsules.

2. The social and economic, as well as environmental factors influence a potential customer, increasing their interest in the supplements used for weight loss. Respondents receive information mainly from a pharmacist and physician, dietician, family and acquaintances.

3. The economic factors have an impact on a limitation of purchasing the expensive dietary supplements. The most often a price as a deciding factor when purchasing the supplement has been indicated by the young individuals and single individuals.

4. The interviewees, in their majority, have indicated an apothecary shop as a place of purchasing the dietary supplements, moreover a herbal shop and the Internet, from which they obtain mainly the individuals who reside in the village areas.

5. With regard to the increasing role of the Internet, it is necessary to educate the consumers with skills related to searching the reliable sources of information about the dietary supplements used in slimming.

\section{REFERENCES}

1. Jeżewska-Zychowicz M. Ocena wpływu wybranych czynników na stosowanie suplementów wśród studentów. Now Lek. 2007;6:459-62.

2. Jarosz M, Bułhak-Jachymczyk B. Normy żywienia człowieka. Podstawy prewencji otyłości i chorób niezakaźnych. Wyd. Warszawa: PZWL; 2008.

3. Reguła J, Gramza-Michałowska A, Stachowiak B. Udział suplementów diety w żywieniu osób dorosłych. Probl Hig Epidemiol. 2011;92:614-6.

4. Krejpcio Z, Skwarek K, Hyżyk AK, Dyba S. Ocena powszechności spożycia suplementów diety w wybranej grupie osób aktywnych sportowo. Probl Hig Epidemiol. 2011;92:935-8.

5. Binkowska-Bury M, Więch P, Januszewicz P. Stosowanie suplementów diety wśród młodzieży akademickiej. Zdr Publ. 2010;120:144-9.

6. Kozłowska L, Pol P. Analiza wykorzystania suplementów i środków spożywczych wspomagających redukcję masy ciała w wybranej grupie studentów. Probl Hig Epidemiol. 2013;94:626-9.

7. Kryska S. Częstość podejmowania działań zmierzających do redukcji masy ciała przez studentki z nadwagą i otyłością pochodzące z górnośląskich uczelni. MONZ. 2014;4:439-43.

8. Spiołek K, Kościołek A, Kania J, et al. Czynniki decydujące o zakupie suplementów diety zawierających witaminy i składniki mineralne przez studentów Śląskiego Uniwersytetu Medycznego. Roczniki PZH. 2011;62:37-40.

9. Wybieralska K. Determinanty stosowania witaminowo-mineralnych suplementów diety oraz napojów funkcjonalnych przez wybrane grupy konsumentów. Probl Hig Epidemiol. 2014;95:70-4.

10. Sadowska J, Szuber M. Ocena stosowanych metod odchudzających oraz używania preparatów wspomagających odchudzanie przez młode kobiety. Roczniki PZH. 2011;62:343-50.

11. Kościółek A, Hartman M, Spiołek K, et al. Ocena czynników wpływających na zakup i stosowanie preparatów witaminowo-mineralnych przez uczniów szkół policealnych. Bromatol Chem Toksykol. 2011;3:987-92.

12. Szpringer M, Olędzka M, Kosecka J, et al. Stosowanie leków dostępnych bez recepty i suplementów diety przez osoby dorosłe $\mathrm{z}$ województwa świętokrzyskiego. MONZ. 2015;21:163-7.

13. Ciszek P, Duma P. Analiza stosowania suplementów diety i świadomości zagrożeń wynikających $\mathrm{z}$ ich pobrania wśród studentów Uniwersytetu Rzeszowskiego. Bromatol Chem Toksykol. 2013;3:404-12.

14. Kasperczyk M. Apteki najlepszym miejscem do kupowania leków bez recepty oraz suplementów diety. Warszawa: PMR Research Group; 2012. [http://www.research-pmr.com/pl/userfiles/file/wp/apteki-najlepszymmiejscem-do-kupowania-lekow-bez-recepty-darmowy-artykul.pdf]

\section{Corresponding author}

Izabela Cichocka

Chair of Quantitative Methods in Economics, University of Information

Technology and Management

2 Sucharskiego Str., 35-225 Rzeszów

tel. +48178661158

E-mail: icichocka@wsiz.rzeszow.pl 